\title{
Determination of Essential Oils Components of Maclura pomifera (Osage Orange) Fruit from Turkey
}

\author{
Rifat BATTALOĞLU *1, Filiz YAĞIZ1 \\ ${ }^{1}$ Niğde Ömer Halisdemir University, Science and Art Faculty, Department of Chemistry, Campus, Nigde, Turkey
}

Received: 04 April 2017 - Revised: 17 August 2017 - Accepted: 03 September 2017

\begin{abstract}
This study was conducted to determine the essential oil components in Macrura pomifera, a North American plant. The essential oil components were determined by GC / MS method after the essential oil isolation of the fruit sample was completed. The relative abundances of the chromatograms obtained as a result of the analyses were compared with the similarity indices of the probable results in the library of the GC / MS for the highest peaks and retention index calculations were made from the retention time. As a result of the analyzes, the structure of 28 essential oil components in the fruit was clarified. When the components were examined, dodecanal $(9.05 \%)$, Eugenol $(8.36 \%)$ and $\alpha$-humulene $(7.84 \%)$ emerged as the first three major components. Other compounds are less common than these three compounds.
\end{abstract}

Keywords: Maclura pomifera, osage orange, essential oils.

\section{INTRODUCTION}

Plants are the main source of the primary metabolites (carbohydrates, proteins and oils) needed to meet the basic nutritional needs of human beings. Apart from these important compounds, some useful substances such as wood, cellulose, gum, rubber are also provided from the plants. In addition to providing food and energy, plant natural products are used in the chemical, nutritional, cosmetic and agricultural fighting sectors, especially in the pharmaceutical industry [1].

Today, medical plants are known as the most active elements of traditional treatment methods. World Health Organization (WHO) data have shown that $80 \%$ of people in developing countries use these treatment methods and 3.3 billion people also benefit from medicinal herbs as a therapy tool $[2,3]$.

Maclura pomifera has a long and interesting history of use by both Native Americans and early pioneers. Its wood was once in demand for making hubs and wheel rims for horse drawn wagons, mine support timbers, posts and many other uses where decay resistance was important. For many years our country is grown as an ornamental plant. It is a plant belonging to the genus Moraceae. The color of young shoots is greenish-gray or light brown. There are many lentis on it. Exiles have thorns on them. When the shoots are torn or cut, they release a liquid in the milk-like appearance. The peak bud is pseudoterminal. The buds are small,

\footnotetext{
*Corresponding Author E-mail: rbattaloglu@ohu.edu.tr
} 
flattened, sphere-shaped. Its leaves 5-12 cm long are egg shaped with long drop-tip. The upper face is bright green, the lower face is light green. It is a full-edged, one-sexed enclosure [4].

Essential oils are obtained from plants. They are liquid at room temperature and can be dragged with water vapor. Essential properties are odorous and oily mixtures. They can evaporate even in the room heat when exposed. Due to pruning, they are known as "essential oil" or "essence" [5, 6]. Essential oils are water-insoluble substances, but they dissolve in water to the extent that their smell is transferred to the water. Soluble in organic solvents such as ethanol, ether, benzene and petroleum ether. Essential oils are water-soluble. A few are heavier than water. They are optically active. The polarized light turns right and left at a certain level. Their reflactive index is high [7].

This research was conducted to determine the essential oil components of Maclura pomifera juice. Firstly, essential oil insulations of fruit samples were carried out in the research. Then, the determination of essential oil components was carried out by GC/MS method.

\section{MATERIAL and METHODS}

\subsection{Material}

Maclura pomifera fruit gathering was performed in August when the fruits were mature. All samples were collected in August, 2012. Different locations in Istanbul and Bursa were determined as the study area. Collection of samples was carried out in these areas. Two samples were taken from each locality. Fruits were dried in the research laboratory under room conditions. After the drying processes, identification of the essential oil compositions was carried out.

\subsection{Method}

$100 \mathrm{~g}$ of sample taken from the dried and milled Maclura pomifera fruit was placed in a $1000 \mathrm{~mL}$ balloon. $700 \mathrm{~mL}$ of water was added and boiled in a Clevenger apparatus for four hours. This process was repeated twice for each sample. The essential oils obtained were dissolved in $0.5 \mathrm{ml}$ of $\mathrm{n}$-hexane (HPLC grade). Dried with $\mathrm{Na}_{2} \mathrm{SO}_{4}$ and stored at $4^{\circ} \mathrm{C}$ in dark colored bottles. Analysis of essential oils was carried out by GC / MS method [8].For this purpose, Thermo brand DSQII model GC / MS device in Pharmaceutical Sciences Research Laboratory of Ege University Faculty of Pharmacy was used. The column of the device is again Thermo TR-WAXMS $60 \mathrm{mx} 0.32 \mathrm{~mm}$ x $0.25 \mathrm{~m}$ and injection volume $1 \mu 1$. The injection was made in three replicates. Relative abundances in sample chromatograms were evaluated for the highest unknown peaks. The possible results from the MAINLIB, WILEY7N and Replic libraries of the GC/MS were determined together with the similarity index. Retention indices of compounds for verification were compared with literature data.

\section{RESULTS}

The following components were found in the structure of the Maclura pomifera fruit; $\mathrm{n}$ hexanol, $\alpha$-pinene, benzaldehyde, hexanoic acid, $\alpha$-terpinene, nonanal, camphor, pinocarvone, 1-nonanol, isoamyl alcohol, decanal, 1-decanol, $\delta$-elemene, p-cresol, $\alpha$-cubebene, eugenol, dodecanal, $\alpha$-humulene, dodecanoic, acid, tetradecanal, cubenol, $\beta$-selinene, octadecane, valerenol, phenol, palmitic acid, linolenic acid and pentacosane. The retention indices and content $(\%)$ of the obtained compounds are shown in Table 1. 
Table 1. Retention indices and content of the obtained compounds.

\begin{tabular}{|c|c|c|c|c|c|}
\hline No & Compound & RI* & LRI** & Formula & Content $\%$ \\
\hline 1 & n-hexanol & 869 & 871 & $\mathrm{C}_{6} \mathrm{H}_{14} \mathrm{O}$ & 2.56 \\
\hline 2 & $\alpha$-pinene & 943 & 949 & $\mathrm{C}_{10} \mathrm{H}_{16}$ & 3.78 \\
\hline 3 & Benzaldehyde & 963 & 960 & $\mathrm{C}_{7} \mathrm{H}_{6} \mathrm{O}$ & 0.59 \\
\hline 4 & Hexanoic acid & 977 & 978 & $\mathrm{C}_{6} \mathrm{H}_{12} \mathrm{O}_{2}$ & 2.71 \\
\hline 5 & $\alpha$-terpinene & 1016 & 1017 & $\mathrm{C}_{10} \mathrm{H}_{16}$ & 0.81 \\
\hline 6 & Nonanal & 1100 & 1101 & $\mathrm{C}_{9} \mathrm{H}_{18} \mathrm{O}$ & 3.21 \\
\hline 7 & Camphor & 1148 & 1146 & $\mathrm{C}_{10} \mathrm{H}_{16} \mathrm{O}$ & 2.49 \\
\hline 8 & Pinocarvone & 1165 & 1165 & $\mathrm{C}_{10} \mathrm{H}_{14} \mathrm{O}$ & 1.86 \\
\hline 9 & 1-nonanol & 1168 & 1171 & $\mathrm{C}_{9} \mathrm{H}_{20} \mathrm{O}$ & 1.66 \\
\hline 10 & İsoamyl alcohol & 1200 & 1201 & $\mathrm{C}_{5} \mathrm{H}_{12} \mathrm{O}$ & 2.32 \\
\hline 11 & Decanal & 1202 & 1204 & $\mathrm{C}_{10} \mathrm{H}_{20} \mathrm{O}$ & 4.25 \\
\hline 12 & 1-decanol & 1251 & 1254 & $\mathrm{C}_{10} \mathrm{H}_{22} \mathrm{O}$ & 3.45 \\
\hline 13 & $\delta$-elemene & 1336 & 1338 & $\mathrm{C}_{15} \mathrm{H}_{24}$ & 0.69 \\
\hline 14 & p-cresol & 1342 & 1344 & $\mathrm{C}_{7} \mathrm{H}_{8} \mathrm{O}$ & 1.10 \\
\hline 15 & $\alpha$-cubebene & 1352 & 1352 & $\mathrm{C}_{15} \mathrm{H}_{24}$ & 1.98 \\
\hline 16 & Eugenol & 1360 & 1359 & $\mathrm{C}_{10} \mathrm{H}_{12} \mathrm{O}_{2}$ & 8.36 \\
\hline 17 & Dodecanal & 1405 & 1409 & $\mathrm{C}_{12} \mathrm{H}_{24} \mathrm{O}$ & 9.05 \\
\hline 18 & $\alpha$-humulene & 1452 & 1455 & $\mathrm{C}_{15} \mathrm{H}_{24}$ & 7.84 \\
\hline 19 & Dodecanoic acid & 1578 & 1580 & $\mathrm{C}_{12} \mathrm{H}_{24} \mathrm{O}_{2}$ & 2.7 \\
\hline 20 & Tetradecanal & 1615 & 1613 & $\mathrm{C}_{14} \mathrm{H}_{28} \mathrm{O}$ & 1.79 \\
\hline 21 & Cubenol & 1648 & 1648 & $\mathrm{C}_{15} \mathrm{H}_{26} \mathrm{O}$ & 1.24 \\
\hline 22 & $\beta$-selinene & 1668 & 1670 & $\mathrm{C}_{15} \mathrm{H}_{24}$ & 2.77 \\
\hline 23 & Octadecane & 1779 & 1800 & $\mathrm{C}_{18} \mathrm{H}_{38}$ & 5.28 \\
\hline 24 & Valerenol & 1869 & 1870 & $\mathrm{C}_{15} \mathrm{H}_{24} \mathrm{O}$ & 1.42 \\
\hline 25 & Phenol & 1928 & 1928 & $\mathrm{C}_{6} \mathrm{H}_{6} \mathrm{O}$ & 0.66 \\
\hline 26 & Palmitic acid & 1966 & 1968 & $\mathrm{C}_{16} \mathrm{H}_{32} \mathrm{O}_{2}$ & 0.54 \\
\hline 27 & Linolenic acid & 2101 & 2102 & $\mathrm{C}_{18} \mathrm{H}_{32} \mathrm{O}_{2}$ & 1.45 \\
\hline \multirow[t]{2}{*}{28} & Pentacosane & 2487 & 2500 & $\mathrm{C}_{25} \mathrm{H}_{52}$ & 1.38 \\
\hline & TOTAL & & & & $77.94 \%$ \\
\hline
\end{tabular}

The analysis results were evaluated and the first three major components were identified. These are dodecanal $(9.05 \%)$, eugenol $(8.36 \%)$ and $\alpha$-humulene $(7.84 \%)$. Other compounds are less common than these three compounds. Dodecanal is also known by the names of lauraldehyde or dodecyl aldehyde. This compound is a colorless liquid. It is a fragrance compound used in cosmetics. It is an organic compound which can be easily converted into acid and alcohol by chemical methods. Eugenol is a phenyl propene compound. It is abundant in the structure of many spices, especially carnations. The compound is widely used in pharmacology. It is also known that pharmacology is also used to give flavor to certain medicines. Insoluble in water but soluble in alcohol and oil. $\alpha$-humulen is abundant in many plants in the world. Pharmacologically due to its analgesic properties.

In Tunisia, a research has been done with the seeds of the same fruit. In this research, a very rich chemical composition was found in the seed of Maclura pomifera. Accordingly, it is thought to be an important nutrient. It has been reported that it can be used as pharmaceutical raw materials in pharmacology. Due to the linenoic acid content they have also come to the conclusion that it may be important for the cosmetic industry [9].

Jerkovic et al. examined the essential oil components with GC-MS in Maclura pomifera fruit samples from Croatia in 2006. According to their work, the phenylpropane derivatives, monoterepenes and other compounds have been encountered in the aliphatic structure. In the structure of the fruit, 39 different essential oil components are encountered. Among these, eugenol (9.9\%) and p-cresol (9.6\%) were identified as the main constituents [10]. 
It is known that the essential oil components of plants vary according to geography and climate. Moreover, no further research has been conducted on this fruit. The results obtained are partially in agreement with other studies.

\section{DISCUSSION}

It is known that plants are effective on the chemical components of the regions they grow. For this reason, it is not expected that the contents or component amounts are the same. It is thought that this study requires more intensive study of the chemical components identified. New studies are planned, which may be important both in cosmetics and pharmacology. The results of the new research reveal that the crust, fruit and seed parts of the fruit are separated from each other to obtain more detailed results. In addition to these, a new study aims to determine the phenolic compounds and acids belonging to the fruit. This research has been seen as a research that will give direction to other studies to be done in the future.

\section{Acknowledgement}

This research was supported by Niğde Ömer Halisdemir University Scientific Research Projects Coordination Unit, FEB 2012/26 BAGEP project.

\section{Conflict of Interests}

Authors declare that there is no conflict of interests.

\section{REFERENCES}

[1]. Phillipson, J. D. (1990). Plants as sources of valuable products, Clarendon Press, Oxford.

[2]. Eloff, J. N. (1998). Which extractant should be used for the screening and isolation of antimicrobial components from plants? Journal of Ethnopharmacology, 60(1), 1-8.

[3]. Keles O, Akü, S, Bakirel, \& T, Alpinar, K. (2001). Türkiye'de yetişen bazı bitkilerin antibakteriyel etkisinin incelenmesi. Turk J Vet Anim Sci, 25, 559-565.

[4]. Wiersema, J. H., \& Leon, B. (2016). World economic plants: a standard reference. CRC press.

[5]. Baytop, T. (1986). Farmakognozi, Cilt:1, İstanbul, İstanbul Üniversitesi Ecz. Fak, Yayınları

[6]. Berk, A. (1953). Esanslar (Eterik Yağlar), İstanbul, Hüsnü Tabiat Matbaası.

[7]. Svigar, A.A., \& Silverstein, R.M., (1981). Monoterpenes: Infrared, Mass, ${ }^{1} \mathrm{H}-\mathrm{NMR}$ and ${ }^{13} \mathrm{C}-\mathrm{NMR}$ spectra and kovats indices, Aldrich chemical Co., Milwaukee, Wiaconsin.

[8]. Adams, R. P.(2004). Identification of Essential Oil Components by Gas ChromatographyMass Spectroscopy, Allured, Carol Stream, IL, USA.

[9]. Saloua, F., Eddine, N. I., \& Hedi, Z. (2009). Chemical composition and profile characteristics of Osage orange Maclura pomifera (Rafin.) Schneider seed and seed oil. Industrial crops and products, 29(1), 1-8.

[10]. Jerkovic, I., Mastelic, J., \& Marijanovic, Z. (2007). Bound volatile compounds and essential oil from the fruit of Maclura pomifera (Raf.) Schneid (osage orange). Flavour and fragrance journal, 22(1), 84-88. 